\title{
Space, Sociality, and Sources of Pleasure: A Response to Sanjay Subrahmanyam
}

\author{
Mana Kia \\ Columbia University \\ mk3586@columbia.edu
}

\begin{abstract}
This response essay engages with the themes of space, sociality, and sources (of pleasure and of scholarship) in Sanjay Subrahmanyam's article in this issue, "The Hidden Face of Surat." I reflect on how the Persianate $a d a b$ that was a dominant cultural form in this port city might cause us to mitigate our analytical concepts when approaching phenomena from different historical contexts. I propose historical inquiry as a form of translation, to look for ways of understanding difference and engaging across it that may or may not be the same as European cosmopolitanism.
\end{abstract}

\section{Keywords}

Persianate - cosmopolitanism - difference - translation - adab - Indian Ocean

Sanjay Subrahmanyam is a master story teller. He has written on a wide array of topics, Indian Ocean and South Asian history, the connected histories of Asia and Europe, and the social, economic, and political fortunes of a broad variety of contexts and the actors that circulated in between. ${ }^{1}$ Here, he has given us a

1 By no means an exhaustive list, but one that illustrates the sheer scope of his work: The Portuguese empire in Asia, 1500-1700: A Political and Economic History (London: Longman, 1993); The Career and Legend of Vasco da Gama (New York: Cambridge University Press, 1997); Penumbral Visions: The Making of Polities in Early Modern South India (New Delhi: Oxford University Press, 2001); Explorations in Connected History, v.1: Mughals and Franks and vol. 2: From the Tagus to the Ganges (New Delhi: Oxford University Press, 2005a and 2005b); Courtly Encounters: Translating Courtliness and Violence in Early Modern Eurasia (Cambridge: Harvard University Press, 2012); and Europe's India: Words, People, Empires, 
vivid account of the rise, development, people, politics, and space of the port city of Surat from its rise in the early 16 th century to its mid-18th-century British capture. Subrahmanyam focuses on the social lives, political transactions and intellectual exchanges between people from different places in this premier Indian Ocean entrepot before European rule. He gives us a three-dimensional sense of this city that challenges some of the historical notions that still hold sway (communal strife as what led to the British takeover, for instance). In addition, he offers us a sustained reflection on what cosmopolitanism outside of Europe may have looked like as an historical phenomenon. Framing his inquiry into Surat are questions of whether "certain political structures were more propitious" and "certain cultural formations" better "able to sustain the complex of attitudes implied in cosmopolitanism than others" (209).

The rise, development, and fortunes of Surat, told through a variety of documents and textual sources, such as letters, travel accounts, maps, chronicles, various European trade company documents, serve to illuminate several aspects about the nature of cosmopolitanism. Subrahmanyam defines the cosmopolitan according to its early modern French usage, as a "citizen of the world," under a "universal peace" entirely consonant with imperial rule (207). This cosmopolitan was constantly on the move, imagined himself a stranger nowhere, and wrote about these sites of concourse with the authority of the Orientalist. Cosmopolitanism thus requires both a knowledge of other cultures and a "certain openness" towards them. Such benign openness implied enjoyment in difference, comfort in living next to one another, and respect in social and economic engagement (208).

Since Subrahmanyam's definition of cosmopolitanism is about an attitude of "pleasure, curiosity and interest," he pursues its voluntary manifestation in a port city, in contrast to the obligations of an imperial capital, where one might encounter "forced mixing, brokered by the naked use of political power." Surat constitutes an alternative place "of great mixing, where many languages, peoples, and cultures came together," a commercial hub, which allows us to consider the relationship between commerce and cosmopolitanism (209).

1500-1800 (Cambridge: Harvard University Press, 2017). Important coauthored work includes: (with Velcheru Narayana Rao and David Shulman) Textures of Time: Writing History in South India, 1600-180o (Delhi: Permanent Black, 2001); (with Muzaffar Alam) Indo-Persian Travels in the Age of Discoveries; and Writing the Mughal World, as well as path-breaking edited volumes such as (ed. with Muzaffar Alam), The Mughal State, 1526-1750 (New Delhi: Oxford University Press, 1998); and (ed. with Claude Markovits and Jacques Pouchepadass), Society and Circulation: Mobile people and Itinerant Cultures in South Asia, 1750-1950 (Delhi: Permanent Black, 2003); and numerous articles. 
My question is about cosmopolitanism. This is a concept that remains bound to its European articulation and history. Can it be ostensibly extracted from that context to provide the ground for transhistorical explorations, for the discovery of similar tendencies elsewhere? What historical, what cultural translations are we encouraged to practice when we generalize a particular concept? Is such a thing as an alternate cosmopolitanism possible or desirable? To look for something called cosmopolitanism in other places-does this means that the things we search for are, in the end, European? Even if we find some of the attributes that define European cosmopolitanism elsewhere, are we justified in isolating those attributes from others that may not fit that definition and labeling them cosmopolitanism? ${ }^{2}$ What is the cost of such an endeavor? As scholars in Islamic studies have recently argued, are there not questions remaining unanswered and things left unseen as larger ideas and practices, where cosmopolitan-like attributes are made to appear? ${ }^{3}$ As we continue to upset European exceptionalism, building off of Subrahmanyam's sustained efforts, we perhaps need to begin with how non-European peoples understood difference, and negotiated it, in places like Surat and elsewhere, before we translate it into European concepts. The challenge is to add new terms alongside cosmopolitanism to explore the plurality to which Subrahmanyam alerts us, to explore how various people in different times and places have related and interacted with one another.

To be clear, I do not argue for radical difference, nor propose jettisoning comparative or even connected histories. I want to extend Subrahmanyam's significant contribution to transregional history, and propose an addendum of sorts, namely, that we linger a moment prior to comparing and connecting, as we historicize from the very beginning, and allow the terms by which we approach our subject to arise in critical engagement with our historical contexts; take them into analytic account on their own terms. Sometimes what we face may be an incommensurability, which only allows for partial connections. When faced with differences, incommensurable or not, we are engaged in translation, between our sources and ourselves. But translation is not only about establishing equivalences. It "articulates one text to another, but it does

2 I expand on some of these ideas in M. Kia, "The Necessary Ornaments of Place: Similarity and Alterity in the Persianate Imaginary." Comparative Islamic Studies (forthcoming in a special issue on "Iranian Cosmopolitanism").

3 This has been trenchantly argued by Shahab Ahmed, What is Islam?: The Importance of Being Islamic (Princeton: Princeton University Press, 2016). Shahzad Bashir has also made this point with respect to thinking about Persian-language tarikh writing as history in his "On Islamic Time: Rethinking Chronology in the Historiography of Muslim Societies." History and Theory 53/4 (2014): 519-44, especially 530-1. 
not mean that translation merely establishes equivalence between two texts, two languages or two groups of people." ${ }^{4}$ To do justice to the comparison, of say, respective ways of understanding differences and relating in spite them, we can make connections based on resemblances while preserving, even highlighting those elements which resist them. This entails accepting and accounting for the simultaneous diachronic aporia of translation and synchronic conceptual categorization. ${ }^{5}$ We can learn from what is incommensurable (and why) as much as from what is comparable. ${ }^{6}$

For me, these questions require us to become self-reflective of our own modernity, to recall that too many of our scholarly concepts, such as community, politics, economy and religion, have a European Christian anatomy that are writ large as universal. ${ }^{7}$ Starting from this awareness means scrutinizing our assumptions and historicizing our analytic categories, so that our engagement with pasts that contain other hermeneutical horizons can be explained in our present. This explanation needs to be understood as an act of translation, one in which lines of difference and their significance may not map comfortably onto those we assume were meaningful points of departure for "mixing." By taking our analytic and conceptual cues from our sources, and critically engaging with them, we begin to fulfill the potential of what Sheldon Pollock has called for, namely a critical philology. ${ }^{8}$ We ask what ideas, practices, concepts meant, the labor they performed at the time, in reception, and what they mean for us, as moderns seeking to say something about the past, to interpret the sources ourselves. Such interpretive translation means thinking with and through our sources and engaging in an interstitial step whereby we recognize and reflect on the convergences and differences between their hermeneutics and our own, before using the latter to explain the former. Rather than just extract meaning about the past from sources, we might also ask ourselves what this meaning means for us, about us, and let that inform our engagement with the past. The hope is that "enlarging our capacity to see things the way other people, people earlier than or otherwise different from us, have seen them" can enable us "to acquire new 'equipment for living' by making available to us

4 N. Sakai, “Translation." Theory, Culture \& Society 23/2-3 (2006): 71.

5 This detailed in A. Lianeri, "A Regime of Untranslatables: Temporalities of Translation and Conceptual History." History and Theory 53 (December 2014): 473-97.

6 For an instance of this kind of project, see Dictionary of Untranslatables: A Philosophical Lexicon, ed. B. Cassin, trans. S. Rendall, C. Hubert, J. Mehlman, N. Stein, and M. Syrotinski, trans. ed. E. Apter, J. Lezra, and M. Wood (Princeton: Princeton University Press, 2014).

7 G. Anidjar, Blood: A Critique of Christianity (New York: Columbia University Press, 2014).

8 For a concise articulation of this ideas, see Pollock, "Philology in Three Dimensions." postmedieval 5/4 (2014): 398-413. 
different conceptions, sometimes astonishingly different conceptions, of what it has meant to be human." (Perhaps Subrahmanyam shares my desire to suspend the question of assumed difference, or at least radical difference between ourselves and our subjects and sources, to entertain the possibility of partial continuity.) I also think that we would do well to heed Pollock's call as part of the fresh eye Subrahmanyam casts (and calls for), in revisiting known sources and looking at new ones.

As Subrahmanyam shows us, there were "cultural formations" that gave people who circulated through the Indian Ocean a commonly understood basis of sociality. I discuss one such formation here in conversation with Subrahmanyam's arguments about space, pleasure, and sources of inquiry. My response to the reflections elaborated in Subrahmanyam's story of Surat is, alas, a far less narratively engaging discussion of Persianate adab. But, as the form of a shared hermeneutical ground upon which to historicize difference, I hope it provides a supplement to help us further understand the meaning and stakes of intercourse, social or otherwise, that occurred between people in Surat and elsewhere in Persianate Asia. ${ }^{10}$

$1 \quad$ Space

The port city is important, Subrahmanyam tells us, because we must look beyond the more commonly examined imperial capital for cosmopolitan intercourse to a place less marked by the coerciveness that power engenders. The founding and existence of Surat before British rule sees the coming of the Portuguese and their attempt to dominate Indian Ocean ports, the simultaneous Ottoman arrival and dispersal across those ports, and the north Indian Timurid conquest of the Gujarati Sultanate, including Surat, all against the background of the more enduring and quotidian Persianate and broader Indian Ocean circulations through the port.

That the port allows consideration of the relationship between commerce and cosmopolitanism is also significant because of "a danger that this relationship slips imperceptibly into a history of European exceptionalism." This is why Subrahmanyam has "chosen a port far away from Europe, even if it did house a certain number of Europeans" (210). The subsequent use of European sources is no doubt necessary to show that Europeans could mix comfortably

9 Ibid.: 399 .

10 Many of this essay's arguments are elaborated in my forthcoming book, Kia, The Persianate: Transregional Sensibilities of Belonging Before Nationalism. 
in the context of trade, and recognize the same among other peoples. In reading archival sources to bring pressure on intellectual history's received truths, Subrahmanyam shows us that European sources can be used to overcome the European exceptionalism that is more the product of Europe's hyperreal image of itself than of historical experience. Further work with different sources, of which we get a tantalizing view (the bilingual Hindavi-Persian map, for instance), can add to the meaning of the proximities that Surat's spatial makeup conveys and give us a sense of other standards by which social intercourse was understood.

Commerce plays a central role in cosmopolitanism's conceptual history and its attendant articulations in law, political practice, and socio-economic transactions. ${ }^{11}$ Anthony Pagden has shown that the question of early modern cosmopolitanism was bound up with the question of legitimate rule of newly acquired overseas colonies. Reckoning with this question led to the valorization of "free" commercial intercourse and its inclusion in European natural law. The violation of this ostensible "natural" right became a justification for warfare and conquest overseas. Given that Surat was India's premier port, where "the goods that were brought from Europe normally found buyers there quite quickly," conceivably there were instances when Europeans, who did not dominate this port, were obliged to play by its rules, to engage in trade brokered by the naked desire for economic gain (223). Voluntariness can never be quite free of instrumentality.

Though concurrently rising at the start of the 16th century, the great early modern Persianate land-based empires across Eurasia, faced a different set of challenges from European empires. The context of simultaneous formulations of universal rule, drawing on the same ideological and intellectual frameworks, and in the same language, facilitated the quickening of elite and less elite circulations. ${ }^{12}$ The result was a larger and deeper spread of shared notions of the proper forms of social intercourse that constituted political and economic relations. We might ask whether what we see in European sources as the pleasure

11 A. Pagden, "Stoicism, Cosmopolitanism, and the Legacy of European Imperialism." Constellations $7 / 1$ (2000): 3-22.

12 For the shared language of universal rule, see A. Azfar, Moin. The Millennial Sovereign: Sacred Kingship and Sainthood in Islam (New York: Columbia University Press, 2012); and for Subrahmanyam's own discussion of Persianate circulation, see "Persians, Pilgrims and Portuguese: The Travails of Masulipatnam Shipping in the Western Indian Ocean, 15901665." Modern Asian Studies 22/3 (1988): 503-30; and "Iranians Abroad: Intra-Asian Elite Migration and Early Modern State Formation." In Merchant Networks in the Early Modern World, ed. S. Subrahmanyam (Aldershot, u k: Valorium, 1996): 72-95. 
of voluntary mixing carried the same values and stakes for Persian-speakers mixing among themselves and with others. And given the long history of understanding individuals from a broad array of backgrounds but versed in the proper Persianate comportment as only partially strange, when did people become other?

Subrahmanyam begins with the emergence of Surat as a major port, discussing its physical development before Timurid conquest. We learn of its notable artillery-fortress, a product of its rise at the moment of the Indian Ocean's militarization caused by the Portuguese arrival and Ottoman intervention in the early sixteenth century. As the city develops over the next two centuries, he speaks of the remarkable "promiscuity" evinced by the port city's layout, in contrast to the more segregated spatial regimes in other European ruled ports (226). As Subrahmanyam shows from a variety of sources, this spatial order signals a kind of social intercourse. Indeed, intermingling is inscribed in the very names of the spaces, such as the neighborhood of saudāgarpüra, combining the Persian word for merchant (saudāgar) and the Sanskrit word for city/ settlement ( $p \bar{u} r a)$, used as "neighborhood" (228). Such combinations whet the appetite to learn more about how Persians and/or Muslims from elsewhere may have experienced a space overlaid with such South Asian combinations. ${ }^{13}$ Regardless, as we see from Subrahmanyam's own account, such named spaces would have been more familiar to West and South Asian residents of the port than to Europeans.

There is plenty of evidence of Sultanate- and Mughal-era alliances between individuals of various backgrounds, an unremarkable phenomenon in both the Indian Ocean or the early modern subcontinent, as Subrahmanyam's work has demonstrated. ${ }^{14}$ In this essay, he draws our attention to the Marjan Shami complex, containing Khwaja Safar Khudawand Khan's tomb and the nearby tomb of Sidi Marjan, Khudawand Khan's military commander. Subrahmanyam shows us how social alliances come to define place, given the way the complex is partly named for Sidi Marjan, whose nearby tomb is the object of local devotion (219). An Ethiopian convert to Islam (Sidi Marjan), executed by the

13 This moniker is particularly noteworthy, since saudägar is a specifically Persian word, not shared with Arabic and only one of the options for naming merchants, such as the more widely shared term tājir.

14 For works detailing this mixing inland, see S. Chandra, Parties and Politics at the Mughal Court, 1707-1740, 4th ed. (New Delhi: Oxford University Press, 2002); M.D. Faruqui, Princes of the Mughal Empire, 1504-1719 (Cambridge: Cambridge University Press, 2012); and R. Kinra, Writing Self, Writing Empire: Chandar Bhan Brahman and the Cultural World of the Indo-Persian State Secretary (Berkeley: University of California Press, 2015). 
Portuguese and revered as a martyr, served an Italian-speaking convert to Islam (Khudawand Khan) who "defected" to Ottoman service, only to end up ruling Surat for the Gujarati Sultans. Their different backgrounds should not obscure the fact that both became Muslims, participated in the defense of Surat against Portuguese aggressors, and, most likely, were able to interact with one another on the basis of a shared set of norms and practices. In other words, the differences which these bonds bridged beg the question of what similarities anchored them. It also raises the question of what counted as difference in the first place. Scenes such as these resonate with the re-emerging urgency of understanding the role trust played in facilitating exchange in economic history, particularly in "cross-cultural trade."15

We may then need to consider how to evaluate the relationship between proximity and the social intercourse it engendered on the one hand, and pleasure, interest, and curiosity, on the other. Why must seeking the company of others need to be free of instrumentality (the reason Subrahmanyam gives for focusing on the port city)? If we consider the Dutch trader who spends his time with Hindu merchants for the stated purpose of "collecting information on who had how much money at Surat" as pleasure, what does this mean about a pleasure embedded in the exigencies of successful trade, or the interests of the Dutch voc (226)?

The last glimpse of Surat's space takes us to the city's graveyards. Subrahmanyam directs us to the intriguing architectural adoption of North Indian Timurid tomb forms by the British. But why did the British and Dutch have separate graveyards? In the context of the dead at least, difference here seems to register according to a concept of nation, separated by language and intraProtestant sectarianism. Was nation (or its early modern cognate, race) a more potent category amongst Europeans than others in Surat? Colin Kidd has given us a complex view from Britain, where early modern ethnicity was filled with internal cleavages, as well as coherent bounds that enabled simultaneous points of convergence with other nations according to broader ethnicities. ${ }^{16}$ The question is whether this complex social ordering and its sedimented history can or should be translated to contexts like Surat, where notions of belonging had their own histories.

\footnotetext{
15 See the essays, especially the introduction, in Religion and Trade:Cross-Cultural Exchanges in World History, 1000-19oo, ed. F. Trivellato, C. Antunes, and L. Halevi (New York: Oxford University Press, 2014).

16 C. Kidd, British Identities Before Nationalism: Ethnicity and Nationhood in the Atlantic World 1600-180o (Cambridge: Cambridge University Press, 1999).
} 
In turning to notions of difference in sources indigenous to the Indian Ocean, and comparing them to those found in Subrahmanyam's European sources, we may be faced with the problem of incommensurability, both with respect to one another, and with respect to us. Seventeenth-century English notions of "nation" were not the same as they are now and "political and confessional alignments were more prominent than pride in ethnic or racial identities." ${ }^{17}$ It seems important, then, to historicize taxonomical distinctions between groups of people, those of Europeans and those of Indian Ocean peoples, and understand which ones mattered and which did not, in order to comprehend the nature of the "mixing" to which Subrahmanyam attends. For instance, given their separate graveyards, were the British and Dutch actually mixing if they socialized? Does the proximity of the tombs of our two 16thcentury converts to Islam testify to "mixing," in death as in life?

Subrahmanyam's picture of Surat runs counter to the dominant view that the so-called "Castle Revolution," significant in that it led to the East India Company's dominance in the region, was due to "a set of deep and immutable cleavages and hostilities between communities resident in the port." By contrast, he emphasizes the way in which "social and commercial dealings regularly cut across sectarian lines" and that this was reflected in the space of the city itself, "where communities did not live in quarters wholly segregated by race or faith" (246). But are race and faith the operative distinctions among and between all of these communities? This is the point in our investigations when we arrive at the moment of translation, when we need to ground the meaning animating a particular act in its cultural context. Like political exchange, economic exchange was not the theoretically impersonal endeavor it is alleged to be in the modern capitalist age. It was embedded in larger forms of sociality that were dominant at the time, generally known in various Indian Ocean and broader Asian locales, and according to which Europeans did not always mix so well. ${ }^{18}$

17 C. Kidd, The Forging of Races: Race and Scripture in the Protestant Atlantic World, 1600-2000 (Cambridge: Cambridge University Press, 2006), 54. Nicholas Hudson tells us that "As we have seen, moreover, European travelers of the seventeenth century were sharply aware of 'national' differences, which they associated with the different political systems, languages, and temperaments of various peoples. Nevertheless ... Europeans before the mideighteenth century identified more strongly with their monarch, their religion, or their native region than with the abstract concept of their 'nation'" in "From 'Nation' to 'Race:' The Origin of Racial Classification in Eighteenth-Century Thought." Eighteenth-Century Studies 29/3 (1996): 256 .

18 Examples of shared practices, most notably gift exchange, abound in S. Gordon, When Asia was the World: Traveling Merchants, Scholars, Warriors, and Monks who Created the "Riches 
Subrahmanyam's cosmopolitanism is a "phenomenon or attitude (if one takes it in that more subjective sense)," or, borrowing from Margaret Jacob, it is an "experience [of] people of different nations, creeds and colors with pleasure, curiosity and interest" (209). Subrahmanyam states that his inquiry into cosmopolitanism as a historical phenomenon is meant to contrast with "a vague transcendent ideal" that is too often drawn "directly into a history of ideas, and more particularly western ideas" (206). But how are we to measure attitudes and phenomena? Where do we locate and find them? Are these emotions? Embodied acts? Do Europeans and Indian Ocean peoples of various sorts evince different social arrangements? Does pleasure always translate together with curiosity and interest, positively?19

It is worth thinking further about how Subrahmanyam's non-European actors might have viewed themselves and their relationship to others, especially since many shared (in common with some Europeans like James Fraser, albeit later) a facility with Persian as a language of power, governance and high culture. Persian was an important language for the Mughal empire, but it was also significant in the Gujarati Sultanate, the Deccani Sultanates, and among the recently arrived Ottomans. ${ }^{20}$

of the East" (Cambridge: Da Capo Press, 2008); and R.E. Margariti, "Coins and Commerce: Monetization and Cross-Cultural Collaboration in the Western Indian Ocean." In Religion and Trade: 192-215. Francesca Trivellato notes that while "a high degree of cultural adaptation was necessary in order for cross-cultural trade to work," and "Hindu merchants learned European languages, ways of doing business, and letter-writing etiquette," nevertheless "the social boundaries between these communities were not blurred as a result of their fiduciary relations," in The Familiarity of Strangers: The Sephardic Diaspora, Livorno, and Cross-Cultural Trade in the Early Modern Period (New Haven: Yale University Press, 2012): 248. Conversely, in intra-Jewish trade deals across regions, commercial relations could break down over lack of shared language, social connections, or practices, ibid.: ch. 10: especially 258-9.

19 "Alexander Dow's History of Hindostan, first published in three volumes between 1770 and 1772 , was dedicated to the king with a candor characteristic of the eighteenth century when one did not need a Michel Foucault to uncover the connection between violence and knowledge: 'The success of Your Majesty's arms,' said Dow, 'has laid open the East to the researches of the curious," Dipesh Chakrabarty, "Postcoloniality and the Artifice of History: Who Speaks for 'Indian' Pasts?” Representations 37 (1992): 5 .

20 On Ottoman Persian traditions, see S.N. Yildiz, "Ottoman Historical Writing in Persian, 1400-16oo." In Persian Historiography, ed. C. Melville (London: I.B. Tauris, 2012): 436-502; and M.U. Inan, "Rethinking the Ottoman Imitation of Persian Poetry." Iranian Studies 50/5 (2017): 671-89; and S.S. Kuru and M.U. Inan, "Reintroducing Hafez to Readers in Rum: 
A Persian was a kind of person who had received a particular form of basic education, through which they understood and engaged with the world. Persian was a textual corpus, but one whose encapsulated meanings also lived and circulated orally, in stories and verse, to broader audiences. Adab, or proper aesthetic and ethical form, was illustrated and conveyed in these texts' stories, and could be modularly detached from its sources and given life orally. Even Europeans, limited in their cultural access, attested to the ubiquity of Persian and of its texts in Surat (231).

Persian $a d a b$ was a type of ethical sensibility that was inherently social, requiring its bearer to interact with the world for its realization. Therefore, the way in which $a d a b$ 's bearer behaved had less to do with how they felt about the object of their interaction, than with the meaning it generated about themselves. Adab was the social ethics and sensibilities by which an individual could perceive the values, stakes, and significance of their ways of being in the world. It was the hermeneutical ground upon which the possibilities of subjectivity and of sociality were built. Its ideal possessor was male, Muslim, and could claim an origin in central Islamic lands, but its belonging was far greater. Adab's distinctive forms were not confined by this ideal, and reciprocal resonances could be found with other forms. Gift-giving and the necessity of exchange to manifest the pledges and obligations that created bonds were not unique to Persians. It was precisely this similarity that allowed for such a wide variety of people to become Persians, or, to interact with them in a more or less harmonious manner. But, in some cases there were limits and failures and both parties did not always understand the meaning of transactions in the same terms.

Indeed, Subrahmanyam shows us a number of moments when Europeans reached their limits, either in the form of social and cultural access or in terms of pleasure. These moments provide comparative fodder to examine the exchanges that others who were not Muslim (Baniyas, Armenians, Parsis), often their brokers, were able to enjoy. These individuals knew the rules of adab, such as patronizing poetry and spending enough of their wealth on charity to manifest the virtuousness required of the prosperous, and it facilitated their ability to exchange and interact with Persians from other communities.

One of the other important departures from the usual accounts of Surat is found in Subrahmanyam's exploration of the intellectual and cultural life of the city, particularly of the Sufi shaykhs who left their marks on the city's built environment. Yet we learn of these individuals largely through their

Sudi's Introduction to his Commentary on Hafez's Poetry Collection." Journal of Turkish Studies 35/1 (June 2011): 11-34. 
engagement with Europeans who seek books and education, through the case of James Fraser in particular. Intellectual life, like economic and political life, was predicated on acknowledged forms of social exchange. Fraser's teachers clearly accepted him as a novice Persian, one whose deficiencies they could correct by training and teaching him proper $a d a b$ in the context of a well-recognized formal relationship between the student-patrons who learned from the teacher-beneficiary (the Chishti Shaykh Muhammad Murad taught Fraser and also produced a text at his request) (239-40). This kind of mixing was acceptable to Persians, to Fraser's teachers, but can we be sure it was understood the same way by Europeans? The failure of reciprocal $a d a b$ on the part of many of these Company students (less so Fraser himself) would tend to indicate not. ${ }^{21}$

Adab gave existential realization to morality, and more broadly, constituted a hermeneutical horizon where meaning depended on the form of its expression or else could not be understood to fully exist. This was a different kind of universality from Europe's, with which it ultimately proved incommensurable. ${ }^{22}$ To grasp it allows us to think about how the Persianate hermeneutical horizon produced differences, but ones that do not necessarily look like, or easily translate into our own.

Persian texts written by regionally bound authors could enjoy transregional mobility, and their stories arrived to other sedentary readers, informing their knowledge of distant people and places. This and other practices of representation provided a way of experiencing familiarity with the unfamiliar that characterized the Persianate, from Muslims to non-Muslims, from the textual to the social, and from the realm of imagination to that of experience (and back again). This logic of adab calls for a consideration of distinctions in terms of aporia. I borrow Jacques Derrida's formulation of aporia as a distinction that has "no limit. There is not yet or there is no longer a border to cross, no opposition between two sides: the limit is too porous, permeable and

21 Mohammad Tavakoli-Targhi also gives us numerous examples of European students effacing their teachers due to incommensurable ideas of authorship and social obligation, particularly across cultural lines, see his Refashioning Iran: Orientalism, Occidentalism and Historiography (London: Palgrave, 2001); and more recently, "Early Persianate Modernity." In Forms of Knowledge in Early Modern Asia: Explorations in the Intellectual History of India and Tibet, 1500-1800 (Durham: Duke University Press, 2011): 257-87.

22 Shahzad Bashir, for instance, shows us different methods of inclusion, where multiple and conflicting streams of time and cosmology were accommodated by narrating them in an unintegrated way alongside one another in a Persian universal history, see his "A PersoIslamic Universal Chronicle in its Historical Context." In History and Religion: Narrating a Religious Past, ed. B.-C. Otto, S. Rau, and J. Rüpke (Berlin: De Gruyter, 2015): 220-3. 
indeterminate."23 Adab's aporetic distinctions gave its bearer a way to be that could accommodate simultaneously being Persian and other things, according to an understanding of otherness that was not based on radical difference. Conceptualizing $a d a b$ as aporetic allows for imagining sensibilities of belonging according to a logic without the border crossing or transgression that presumes discrete categories inhering in the idea of hybridity or mixing.

Social $a d a b$ was not just proper conduct, then, but also the attitudes and sensibilities intimately connected to these idealized forms of behavior. In order for one to have proper moral substance, one needed to manifest it through engagement with the world. Behavior brought substance into being, just as substance guided behavior. These must be considered as indivisible parts of a whole, an ontological continuum through which virtue was made intelligible. Akhläq are moral qualities that cannot be known or realized into existence without their corresponding $a d a b$ or proper form, of which they are both distinct and an integral part. In this sense then, adab was also an indicator of $a k h l \bar{a} q$, a sign in excess of itself, a social ethics of morality. Thus, those who were in possession of moral qualities were also refined in conduct (adab). Similarly, one's states $(a h \mathfrak{q} \bar{a} l)$ had to be manifest in a particular way to be realized. ${ }^{24}$ So there is some justification for the repeated practice of socializing being indicative of a particular state of affinity amongst Persians. But what about Europeans, whose very ideas of sentiments or passions (emotions being a relatively minor concept at this point $)^{25}$ were undergoing change in the 17 th century, such that feelings (like pleasure and curiosity) were becoming essentially interior and expressions secondary?26

23 Aporias: dying - awaiting (one another at) the "limits of truth" (mourir-s'attendre aux "limites de la vérite") (Stanford: Stanford University Press, 1993): 20. I elaborate on the aporia of adab in The Persianate.

24 E. Naaman, "Nurture over Nature: Habitus from al-Fārābī through Ibn Khaldun to 'Abduh." Journal of the American Oriental Society 137/1 (2017): 4.

25 T.T. Dixon, From Passions to Emotions: The Creation of a Secular Psychological Category (Cambridge: Cambridge University Press, 2004).

26 A. Bryson, From Courtesy to Civility: Changing Codes of Conduct in Early Modern England (Oxford: Clarendon Press, 1998): ch. 6. She outlines the growth of concern over "sincerity" in expression arising from a shift in the essential locus of substance, where morality and civility could be viewed as opposed. Even so, there was something more existentially fundamental to the existence of a moral state in its proper enactment than merely making it "socially visible and effective," as Bryson describes for Europe (198). This likely has to do with the understanding of virtue as inner and civility as outer, something that came to be mapped on to a sharpening split between body and mind of which Descartes is an example. The epistemology of zāhir/bāțin, maps onto a manifest and hidden dyad that may appear (to the uninitiated) unrelated or even contradictory, but was part of the 
The specific articulation of qualities and their manifestation as and through conduct were part of a cultural matrix of the Persianate, a particular moral imagination according to which the social was made intelligible. It meant something to behave in a certain way because there was an audience, for instance, who understood that to have great wealth literally required one to spend it in certain ways to benefit the less well off, or be morally deficient. In terms of trade, as well as other forms of social and political cooperation involving trust, this sort of perception and its mutual resonances across lines of difference was quite crucial.

Let us turn to some examples of how Persians understood themselves and those we consider others. First, if we decouple the identifier of an Iranian place of origin from the possessor of Persianate $a d a b$, we make room for considering that people, from a far vaster area, shared common understandings of what their origins meant and in what terms, even if their particularities differed. Second, place was only one small component of the notion of origin. Homelands could be multiple, listed as itineraries through which a person or their ancestors had moved. Regardless, homes were small places, usually cities or town, not polities or even provinces. Third, far more important than place, origin was understood in terms of lineages - natal, as well as other lineages which mattered at least as much, such as those of service, learning or larger social collectives. These lineages linked people and places in ways that belie the mono-logic of religion, an origin reductively conceived of as place, or natal lineage as the basis of difference.

Let me provide examples from two eighteenth-century Persians writing in the subcontinent. Āzād Bilgrāmī’s biography of Murshid Qulī Khān "Makhmūr" demonstrates the way learned lineage fits the overall story of origin:

His original name is Mirzā Luțfullah. His father, Hajjī Shukrullah Tabrīzī, entered Hindustan from the land (diy $\bar{a} r$ ) of Iran and established his residence at the port of Surat. Murshid Qulī Khān was born in Surat in the year AH 1095/AD $1684 \ldots$ After he had arrived at the age of cognition (tamyizz) he was at the service (khidmat) of Āqā Ḥabībullah Isfahānī, one of the established men of learning resident in Surat, who was one of the senior students (shägird-irashìd) of [the prominent Safavid scholar] Āqā Husayn Khwānsarī. ${ }^{27}$

same unified whole, an epistemology of truth undergirded by the hegemonic concept of tawhìd, or God's unity (See Ahmed, What is Islam?: 335).

27 Ghulām 'Alī Āzād Bilgrāmī, Daftar-i Sānī-yi Ma'āsir al-kirām, mawsām bah Sarv-i Āzād, ed. 'Abdullah Khān and Mawlawī 'Abd al-Ḥaqq (Lahore, 1913): 221-2. 
Born in Surat, Murshid Qulī Khān had links elsewhere. He was the son of a migrant from Safavid domains and educated by another migrant in Surat, who was the student of one of the most illustrious late Safavid ulama. The benefits of this kind of service included location in a learned lineage that appears across Timurid domains. The other half of the entry mirrors these exalted origins, with details of illustrious patrons and high positions in Bengal and Hyderabad. ${ }^{28}$ Here, late Safavid learned lineages are rooted in Persianate sites of the subcontinent.

Learning and service were amongst the important lineages that commemorated origin. In the preface to his tazkirah, Gul-i Ra'nā, "Lachmī Nara'in," describes himself as "pen-named Shafìq, Awrangābādī, who from the beginning of eternity (rūz-i azal) has his excellency Āzād Bilgrāmīs brand of slavery (dagh-i ghulāmī) on his forehead." 29 Writing in Awrangabad, he identifies himself as Awrangabadi, which, when uttered in that place, seems to indicate an immutable and autonomously native identification. Yet Shafiq is speaking to Persians from elsewhere or in another locale. He introduces himself with a proper name (ism), a penname (takhallus), and a place moniker (nisbat), before distinguishing himself as literally marked by his teacher. ${ }^{30}$ Sayyid Ghulam "Ali "Azad" Bilgrami is the noted poet, scholar, and participant of the prominent Nakhshbandi takiyyah of Awrangabad. ${ }^{31}$ Shafiq's relationship with his teacher is a lineage of knowledge, part of his origin.

Later, in his biography, before any mention of his own birth, he narrates this story:

28 After the death of his father, Murshid Qulī Khān went to Bengal to trade. He caught the attention of the Nawwāb of Bengal, Shuja' al-Dawlah, became his son-in-law, and spent many years as governor of Orissa. When "fate disposed him of his position," he entered into the service of the Nizām of Hyderabad until the end of his days. Over his lifetime, Murshid Qulī Khān was often simultaneously, a poet, mystic, merchant, and statesmen/ administrator, ibid.: 221-2.

29 Lachhmī Narā‘in Shafīq Awrangābādī, Gul-i Rảnāa, British Library manuscript, I.o. Islamic 3692: fol. 1 b.

30 For more on structures of naming, see A. Schimmel, Islamic Names (Edinburgh: Edinburgh University Press, 1989).

31 For more on Azad, see Sayyid Ḥasan 'Abbās, Aḥvāl va āsāār-i Mīr Ghulām Alı̀ Āzād Bilgrāmī (Tehran: Bunyād-i Mawqūfāt-i Duktur Maḥmūd Afshār Yazdī, 2005); and C.W. Ernst, "Reconfiguring South Asian Islam: From the 18th to the 19th Century." Comparative Islamic Studies 5/2 (2011): 247-72. For more on this institution and its textual culture, see N. Green, "The Uses of Books in a Late Mughal Takiyya: Persianate Knowledge Between Person and Paper." Modern Asian Studies 44/2 (2010): 241-65. 
Shafìq pen-named, Lachmī Nara'in Māthur, the author of these pages, is of the Kathrī Kapūr people (qawm). His grandfather, Bhavānī Dās, accompanied 'Ālamgī's camp from Lahore to the Deccan. He laid the colors of settlement in Awarangabad and entered into the relationship of service (șigha-yi nawkarì). He achieved great honor [in this work] and came to be possessed of children. His middle son, Rā'i Nisā Rām, who is father of the author, was ten years old when Bhavānī Dās gathered his things for his last journey [died]. The father [Rāī Nisā Rām] was educated in the shadow of Lālā Jasvant Rāî̀'s affection, [a man] who was both a grandfather (jaddī) and qualified in science and learning ( ${ }^{(i / m}$ wa fazl). In the time of Navvab Asaf Jāh, he [Rā'ì Nisā Rām] was appointed to deputyship of the administration (pishkeāri-yi sidārat) of the six șubas of the Deccan and until the time of writing he continues in this work, for what is now forty years. The deceased Navvab Samsām al-Dawlah Bahadur Awrangbadi, who was unmatched in his day in sociability and beneficence (ädam-shināsi wa fayz-risānì), in the days of his deputyship, granted him [Rāî Nisā Rām] a manșab [rank] at the request of his excellency Āzād Bilgrāmī. Favored with the deputyship of the paymastership (bakhshi al-mamālik) of the Deccan, he incorporated service to the dervishes ( fuqarā) with service to the nobles $($ umara $\bar{a})$. He always observed the manner of conferring the kindness of favors, and my father accomplished both forms of dignified service according to all the necessary customs $\left(\bar{a}^{\prime} \bar{i} n\right) .{ }^{32}$

Shafiq's origins are narrated in terms of what we would call jāti (not a term he uses) and paternal ancestry, alongside and intertwined with lineages of teachers and patrons. His origins and their names, Khatri Kapuri (and its subdesignation, Mathur), Lahori and Awrangabadi, imperial and paternal, come together to make him a Hindu, a Timurid administrator, and a Persian man of letters. Prominent in this story is his father's mastery of the adab (as ethics) appropriate to his social location in imperial administrative service, a product of many other relationships. Rāî Nisā Rām's perfect enactment of the expected customs of conduct toward all kinds of people - from the masters of the hidden world (dervishes) to those of this manifest world (nobles)—indicate the basis of Shafiq's own learned potential as a master of adab. Shafiq's account of his origins is typical in its primary emphasis on genealogies and in the specifics of his occupation. In the midst of these origins, place appears but does not

32 Tazkira-yi Gul-i Ra'nā: Fașl-i Duwwum dar zikr-i nukta pardāzān-i Așnāmiyān (Hyderabad: 'Ahd-i Afarīn, 1223/1808-9): 92-93. 
alone constitute origin. Rather, place was always bound up in other kinds of lineages and almost never singularly given.

For Persians, this mastery of $a d a b$, in language and conduct, was the means by which they connected with people who were not part of the same religious communities, collective lineages, social locations, occupational groups, or localities. Adab created terms by which they belonged together, a framework of relationships and way of relating, such as lineages of learning and service. Socially recognized forms of extralegal kinship were a vital part of origins, and coherently part of a spectrum also constituted by legally sanctioned relationships. These modes of connection, grounded in social practices of companionship, resonate with the way Sufi orders were formed and could function, whereby individuals from different families or even parochial communities were bound up in chains of esoteric learned lineages. ${ }^{33}$ These socially recognized lineages were not legally bound though they could be as or even more meaningful as those that were. ${ }^{34}$

It seems that a shared understanding of what it meant to have the kind of intercourse upon which political, economic and social exchanges took place marked something important in Surat. Before European dominance, access to Persianate cultural forms, both through the language and also mastery of its social ethics of proper comportment, made the difference between access and not. Indeed, it seems to have made the difference between enjoyment or not. The port is certainly a noteworthy (albeit not a unique) site for pursuing these questions of difference, social intercourse, and its limits, which bring us to the problem of sources.

\section{$3 \quad$ Finally, Sources}

Subrahmanyam points to the difficulty of achieving a "balanced" view of Surat, given the relative plethora European language sources, of which he shows his usual expert use (220-21). He mentions and makes some use of the other available sources in Persian. But the relative paucity of easily accessible

S. Bashir, Sufi Bodies Religion and Society in Medieval Islam (New York: Columbia University Press, 2013): 78-104; and A.F. Buehler, Sufi Heirs of the Prophet: The Indian Naqshbandiyya and the Rise of the Mediating Sufi Shaykh (Columbia: University of South Carolina Press, 2008): 82-97. For a description of initiation in Sufi based craft guild orders, see A. Loewen, "Proper Conduct (Adab) is Everything: The Futuwwat-namah-i Sultani of Husayn Va'iz-i Kashifi." Iranian Studies 36/4 (December 2003): 543-70. Kāshifîs repeated injunctions that those initiated be Muslims indicates non-Muslim participation and confraternities.

I elaborate on these ideas at length in chapter 3 of The Persianate.

JESHO 61 (2018) 256-276 
non-European sources should be heard as a clarion call for scholars to comb public, private, and family archives for information in other languages, which may narrate and/or give evidence about these issues from other perspectives. ${ }^{35}$ One wonders whether Parsi archives may contain any documents in Persian and/or Gujarati, whether further sources in Persian or other languages languish in various sites in India, or collect dust in the family collections (majmu'ahs) that are starting to be accessed in Iran. Not all these new sources will look to us like the official documentary evidence proper to history, but they are just what is needed to make room for other historical logics in our translation efforts. ${ }^{36}$ Accompanying these new sources must be historical lenses, translation tools and sensibilities capable of evaluating phenomena such as pleasure, interest, and curiosity, as well as the differences understood and negotiated. We need to let our analytic terms be informed and enriched by our sources, to ask, what are these sources, for whom are they written, and what might be the political stakes and hermeneutical ground upon which they rest?

Subrahmanyam's essay remarkably brings to our attention the politics of space, and the way in which the social intercourse of mercantile exchange brought different groups into proximity, both those strange and those more familiar (other Muslims, Persian-speakers, or Indian Ocean peoples), in a port unmarked by later European colonial segregationist regimes. If cosmopolitanism is the pleasure in difference, does it in fact depend on an idea of radical difference? If this is the case, then perhaps it is an inherently modern phenomenon, one possibly confined to Europe. In Persianate Asia, in the aporias of $a d a b$, there were ways to make partial linkages with the different, strange, and unfamiliar that enabled forms of interaction. ${ }^{37}$ There may or may not be cosmopolitanism there. And perhaps, there was no need for it.

\section{Bibliography}

'Abbās, Sayyid Ḥasan. 2005. Aḥvāl va āsāarr-i Mīr Ghulām Ál̄ Āzād Bilgrāmì. Tehran: Bunyād-i Mawqūfāt-i Duktur Mạ̣mūd Afshār Yazdī.

Anidjar, Gil. 2014. Blood:A Critique of Christianity. New York: Columbia University Press.

35 Some of this work has already begun, to great effect, see K. Pant, "Homes of Capital: Merchants and Mobility across Indian Ocean Gujarat" (Unpublished Ph.D. diss., Duke University: 2015).

36 That different types of histories may require sources different from those conceived as such at the time history was the story of great men and great events is the logic of Women's Worlds in Qajar Iran (http://www.qajarwomen.org/en/).

These particular ideas are argued in Kia, "The Necessary Ornaments of Place."

JESHO 61 (2018) 256-276 
Ahmed, Shahab. 2016. What is Islam?: The Importance of Being Islamic. Princeton: Princeton University Press.

Alam, Muzaffar and Sanjay Subrahmanyam, ed. 1998. The Mughal State, 1526-1750. New Delhi: Oxford University Press

Alam, Muzaffar and Sanjay Subrahmanyam. 2007. Indo-Persian Travels in the Age of Discoveries, 1400-180o. Cambridge: Cambridge University Press.

Alam, Muzaffar and Sanjay Subrahmanyam. 2012. Writing the Mughal World: Studies on Culture and Politics. New York: Columbia University Press.

Āzād Bilgrāmī, Ghulām 'Alī. 1913. Daftar-i sānī-yi Ma'āsir al-kirām, mawsām bih Sarv-i $\bar{A} z \bar{a} d$. Ed. 'Abdullah Khān and Mawlavī 'Abd al-Haqq. Lahore.

Bashir, Shahzad. 2013. Sufi Bodies Religion and Society in Medieval Islam. New York: Columbia University Press.

Bashir, Shahzad. 2014. On Islamic Time: Rethinking Chronology in the Historiography of Muslim Societies. History and Theory 53/4: 519-44.

Bashir, Shahzad. 2015. A Perso-Islamic Universal Chronicle in its Historical Context. In History and Religion: Narrating a Religious Past, ed. Bernd-Christian Otto, Susanne Rau, and Jörg Rüpke. Berlin: De Gruyter: 209-225.

Bryson, Anna. 1998. From Courtesy to Civility: Changing Codes of Conduct in Early Modern England. Oxford: Clarendon Press.

Buehler, Arthur F. 2008. Sufi Heirs of the Prophet: The Indian Naqshbandiyya and the Rise of the Mediating Sufi Shaykh. Columbia: University of South Carolina Press.

Cassin, Barbara, ed. 2014. Dictionary of Untranslatables: A Philosophical Lexicon, trans. Steven Rendall, Christian Hubert, Jeffrey Mehlman, Nathanael Stein, and Michael Syrotinski. ed. Emily Apter, Jacques Lezra, and Michael Wood. Princeton: Princeton University Press.

Chakrabarty, Dipesh. 1992. Postcoloniality and the Artifice of History: Who Speaks for 'Indian' Pasts? Representations 37: 1-26.

Chandra, Satish. 2002. Parties and Politics at the Mughal Court, 1707-1740. 4th ed. New Delhi: Oxford University Press.

Derrida, Jacques. 1993. Aporias: dying — awaiting (one another at) the "limits of truth" (mourir — s'attendre aux "limites de la vérité"). Stanford: Stanford University Press.

Dixon, Thomas T. 2004. From Passions to Emotions: The Creation of a Secular Psychological Category. Cambridge: Cambridge University Press.

Ernst, Carl W. 2011. Reconfiguring South Asian Islam: From the 18th to the 19th Century. Comparative Islamic Studies 5/2: 247-72.

Faruqui, Munis D. 2012. Princes of the Mughal Empire, 1504-1719. Cambridge: Cambridge University Press.

Gordon, Stewart. 2008. When Asia was the World: Traveling Merchants, Scholars, Warriors, and Monks who Created the 'Riches of the East'. Cambridge: Da Capo Press. 
Green, Nile. 2010. The Uses of Books in a Late Mughal Takiyya: Persianate Knowledge Between Person and Paper. Modern Asian Studies 44/2: 241-65.

Hudson, Nicholas. 1996. From 'Nation' to 'Race:' The Origin of Racial Classification in Eighteenth-Century Thought. Eighteenth-Century Studies 29/3: 247-64.

Inan, Murat Umut. 2017. Rethinking the Ottoman Imitation of Persian Poetry. Iranian Studies 50/5: 671-689.

Kia, Mana. 2018. The Necessary Ornaments of Place: Similarity and Alterity in the Persianate Imaginary. Comparative Islamic Studies: forthcoming.

Kia, Mana. The Persianate: Transregional Sensibilities of Belonging Before Nationalism: forthcoming.

Kidd, Colin. 1999. British Identities Before Nationalism: Ethnicity and Nationhood in the Atlantic World 1600-180o. Cambridge: Cambridge University Press.

Kidd, Colin. 2006. The Forging of Races: Race and Scripture in the Protestant Atlantic World, 1600-200o. Cambridge: Cambridge University Press.

Kinra, Rajeev. 2015. Writing Self, Writing Empire: Chandar Bhan Brahman and the Cultural World of the Indo-Persian State Secretary. Berkeley: University of California Press.

Kuru, Selim S. and Murat U. Inan. 2011. Reintroducing Hafez to Readers in Rum: Sudi's Introduction to his Commentary on Hafez's Poetry Collection. Journal of Turkish Studies 35/1: 11-34.

Lianeri, Alexandra. 2014. A Regime of Untranslatables: Temporalities of Translation and Conceptual History. History and Theory 53: 473-97.

Loewen, Arley. 2003. Proper Conduct (Adab) is Everything: The Futuwwat-namah-i Sultani of Husayn Va'iz-i Kashifi. Iranian Studies 36/4: 543-70.

Margariti, Roxani Eleni. 2014. Coins and Commerce: Monetization and Cross-Cultural Collaboration in the Western Indian Ocean. In Religion and Trade: Cross-Cultural Exchanges in World History, 1000-19oo, ed. Francesca Trivellato, Cátia Antunes, and Leor Halevi, 192-215. New York: Oxford University Press.

Markovits, Claude; Jacques Pouchepadass, Sanjay Subrahmanyam. 2003. Society and Circulation: Mobile people and Itinerant Cultures in South Asia, 1750-1950. Delhi: Permanent Black.

Moin, A. Azfar. 2012. The Millennial Sovereign: Sacred Kingship and Sainthood in Islam. New York: Columbia Univ. Press.

Naaman, Erez. 2017. Nurture over Nature: Habitus from al-Fārābī through Ibn Khaldun to 'Abduh. Journal of the American Oriental Society 137/1: 1-24.

Pagden, Anthony. 2000. Stoicism, Cosmopolitanism, and the Legacy of European Imperialism. Constellations 7/1:3-22.

Pant, Ketaki. 2015. Homes of Capital: Merchants and Mobility across Indian Ocean Gujarat. Ph.D. diss., Duke University.

Pollock, Sheldon. 2014. Philology in Three Dimensions. postmedieval 5/4: 398-413. 
Rao, Velcheru Narayana; David Shulman; Sanjay Subrahmanyam. 2001. Textures of

Time: Writing History in South India, 160o-180o. Delhi: Permanent Black.

Sakai, Naoki. 2006. Translation. Theory, Culture \& Society 23/2-3: 71-8.

Schimmel, Annemarie. 1989. Islamic Names. Edinburgh: Edinburgh University Press.

Shafīq Awrangābādī, Lachhmī Narāin. Gul-i Ra’nā. British Library manuscript, I.o. Islamic 3692.

Shafīq Awrangābādī, Lachhmī Narāin. 1808-9. Tazkira-yi Gul-i Ra’nā: Fasl-i duwwum dar zikr-i nikta pardāzān-i așnāmiyān. Hyderabad: 'Ahd-i Afarīn.

Subrahmanyam, Sanjay. 1988. Persians, Pilgrims and Portuguese: The Travails of Masulipatnam Shipping in the Western Indian Ocean, 1590-1665. Modern Asian Studies 22/3: 503-30.

Subrahmanyam, Sanjay. 1993. The Portuguese empire in Asia, 1500-1700: A Political and Economic History. London: Longman.

Subrahmanyam, Sanjay. 1997. The Career and Legend of Vasco da Gama. New York: Cambridge University Press.

Subrahmanyam, Sanjay. 1996. Iranians Abroad: Intra-Asian Elite Migration and Early Modern State Formation. In Merchant Networks in the Early Modern World, ed. Sanjay Subrahmanyam. Aldershot, U K: Valorium: 72-95.

Subrahmanyam, Sanjay. 2001. Penumbral Visions: The Making of Polities in Early Modern South India. New Delhi: Oxford University Press.

Subrahmanyam, Sanjay. 2005a. Explorations in Connected History: Mughals and Franks. New Delhi: Oxford University Press.

Subrahmanyam, Sanjay. 2005b. Explorations in Connected History: From the Tagus to the Ganges. New Delhi: Oxford University Press.

Subrahmanyam, Sanjay. 2012. Courtly Encounters: Translating Courtliness and Violence in Early Modern Eurasia. Cambridge: Harvard University Press.

Subrahmanyam, Sanjay. 2017. Europe's India: Words, People, Empires, 1500-180o. Cambridge: Harvard University Press.

Tavakoli-Targhi, Mohamad. 2001. Refashioning Iran: Orientalism, Occidentalism and Historiography. London: Palgrave.

Tavakoli-Targhi, Mohamad. 2011. Early Persianate Modernity. In Forms of Knowledge in Early Modern Asia: Explorations in the Intellectual History of India and Tibet, 1500180o, ed. Sheldon Pollock. Durham: Duke University Press: 257-87.

Trivellato, Francesca. 2012. The Familiarity of Strangers: The Sephardic Diaspora, Livorno, and Cross-Cultural Trade in the Early Modern Period. New Haven: Yale University Press.

Trivellato, Francesca, Cátia Antunes, and Leor Halevi, ed. 2014. Religion and Trade: Cross-Cultural Exchanges in World History, 1000-19oo. New York: Oxford University Press.

Yildiz, Sara Nur. 2012. Ottoman Historical Writing in Persian, 1400-16oo. In Persian Historiography, ed. Charles Melville. London: I.B. Tauris: 436-502. 